\title{
Comparison of Renovation of Damaged Fabrics with Smart Growth Approach (Case Study: Renovation of Qarani Neighborhood in Mashhad)
}

\author{
Rezvani Kakhki Saeid ${ }^{1} \&$ Rahnama Mohammad Rahim ${ }^{2}$ \\ ${ }^{1}$ Ferdowsi University of Mashhad, PhD student of International Branch, Department of Urban Planning, Iran \\ ${ }^{2}$ Ferdowsi University of Mashhad, Associated professor of geography and Urban Planning, Iran \\ Correspondence: Rezvani Kakhki Saeid, Ferdowsi University of Mashhad, International Branch. Address: Reza \\ Blv. Ferdowsi University of Mashhad. E-mail: rezvanibox1@gmail.com
}

Received: January 2, 2016

Accepted: February 22, 2016

Online Published: July 7, 2016

doi:10.5539/mas.v10n10p106

URL: http://dx.doi.org/10.5539/mas.v10n10p106

\begin{abstract}
A special position is dedicated to preservation and reconstruction of old city centers in the world with the aim of cultural, economic, social and historical revival. Economic revival is considered as an important strategy which means boosting suitable and harmonious economic activities to both strengthening the existing activities and attracting new economic activities. Over time, the centers of cities gradually wear out and their importance and application decrease. This will lead to migration of city center residents to suburbs and consequently horizontal growth of cities. Smart growth and form-oriented regulations formulation known as transport regulations is as one of the introduced approaches in developed cities to deal with horizontal growth and urban sprawl. In the recent study, the processes of old areas reconstruction are compared to the transport criteria and indices of smart growth to deal with horizontal growth. We have attempted to make it possible to evaluate local projects and reconstruct damaged urban textures. In addition, hypotheses were examined using mean comparison test to determine the conformity of these methods with the smart growth. Results showed that the local project of reconstruction of Qarani neighborhood in Mashhad is inconsistent with the smart growth regulations.
\end{abstract}

Keywords: combined land use, neighborhood, new urbanism, smart growth, transport design

\section{Introduction}

Scientific, technical and economic developments in the human life affect the life style and activity in local communities. Development of knowledge and technology have growing trend, while urban textures are designed and constructed in a long time. So that, as time passes social and economic developments are accelerated with rapid scientific and technical developments which cause new needs in human lives. Response to the needs is beyond what that can be realized in the available urban living and activity spaces. Therefore, measures have already been taken are not able to meet the needs of new generations who are born in the old urban neighborhoods and new measures should be adopted based on modern ideas as approaches different from past and not in the sense of denying the context (Andalib, 2008). City center is considered as historic turning point, ever living heart of urban civil society, the heart of financial and economic credits, and a place that includes most attractive public buildings of services and management and education, a place in which various networks of technical-welfare services cut each other in different levels and come together with the highest density. These are among points that can be mentioned in a quick visual interpretation. Clearly, it is a center or a hearth for a city that based on what we mentioned; its life is as long as all human beings' lifetime and brings together different experiences, shows the identity and originality of urbanities, who set the scene for shaping the cultural, civil and literary nature of the city over their generations (Falamaki, 2005). The movement of city centers revival has more than 150 years of history. It initiated with the activity of Baron Haussmann, mayor of Paris to renovate the center of city in 1850s and entered a new stage with the Le Corbusier designs as shining city in 1920s. After the World War II, the Le Corbusier' principles were approved by world governments which knew that as an easy and quick response to renovation needs and select him as a real propagandist of modern urban development. Consequently, a revision of city centers renovation patterns and transformation of renovation to retrofitting and preserving patterns became important since 1960s. In fact, social-economic planning and relying on the people 
instead of body and primacy of culture and heritage over economy were introduced. Preference of external expansion (horizontal growth) or internal expansion (smart growth) was considered by specialists of the urban planning (Rahnema, 2009). Since 1980s, increasing number of American urban developers presented some theories on aging of city centers and horizontal expansion of suburbs which were dispersed, based on automobile traffic and with long distance and from city centers. Evolution of these theories led to the emergence of new urbanism movement based on humanistic urban planning. In the urbanism culture, new urbanism is supported by an attitude toward planning and urban design with emphasis on physical characteristics of neighborhood units and smart growth (Rahnema, 2012). Ideas related to the new urbanism design principles and conventional neighborhood units have been derived from conventional design principles consistent with the human's position in the city. Every neighborhood has a certain center and edge, its optimal size is a quarter of a mile from center to the edge and it includes a balanced combination of different activities such as living space, shopping, work, school, leisure time and worship. It forms the constructed spaces and internal riding network and is prior to the public spaces and location of urban public places (Einifar, 2007). Mashhad city has special national and regional importance due to the presence of the Shrine of the eighth Imam of the Shiites and renovation and reconstruction projects of central parts of city requires precise evaluation. On this basis, designing process of one of the old central neighborhoods of the city is compared with principles of smart growth.

\section{Literature Review}

Form-based codes were first implemented in the California as one of the urban smart growth concepts. Displacement of development principles by form-based codes began 15 years ago. Since then, it was emphasized to apply form-based codes to some urban neighborhoods. As a result, a combination of both text regulations that buildings represent the space and non-textual principles in which buildings easily are present, is applied (Talen, 2013). Hence, urban smart growth today's is able to present almost complete indices and criteria for urban planning and designing. The indices are gathered from reliable sources and are categorized and summarized in a table. We use the multi criteria analysis method to evaluate the consistency of urban areas with the smart growth principles and transit design. Combination of spatial data and their features are assessed using this method and consistency score is calculated finally for every index used in analyses. The analytic hierarchy process (AHP) is a flexible, powerful and simple method which is applied when different decision making criteria make difficult the selection between options. AHP method was first proposed by Tomas Thomas L. hour in 1980 and has already been used in different sciences. It significantly decreases the conceptual complexity of decision making since two components (paired comparison) are evaluated at the same time. It has 3 main steps: a) Production of paired comparison matrix. b) Standard weights calculation citizenship right. c) Estimation of consistency ratio (Ziari, 2010). Designing the Qarani and Horameli neighborhoods in Mashhad which was performed by Mehrazan consultant engineers was selected as one of the newest reconstruction projects of central worn out neighborhoods. All required indices and criteria for urban smart growth adaptation in the local project of the Qarani neighborhood in Mashhad were deduced based on documentations presented in the consultant report and a score from 0 to 100 was considered for every criterion. Finally, results of this table are judged based on mean comparison statistical model to test the hypothesis acceptance and consistency of planning process with smart growth approach was evaluated.

\section{Theoretical Foundations}

Once, the urban centers were regarded as desirable places for living. some issues such as traffic congestion, environmental degradation, stagnant houses, low quality of public schools, crime, lack of access to open space and destruction of infrastructures occurred in the city core With economic and population growth which led to destruction of city center. In recent years, many communities have decided to establish the development pattern of their societies based on smart growth principles and strategies. These principles will increase the land uses access, decreases the share of use and travel with means of transportations and creates a society with combined uses (Rahnema, 2008). New homes are preferred to be located near the workplace to decrease the problems related to transportation, traffic and air pollution. Access to local stores and public transportation and services is also emphasized (Edwards et al., 2007). Horizontal expansion is a term entered to the research literature in the recent half century as "sprawl" word and today's is the topic of most urban seminars in developed countries. Some researchers believe that sprawl is resulted from low density, dispersed and discontinuous urban development and expansion toward out of range areas and low density suburb areas along with dominance of private cars in transportation (Rahnema, 2008). Opposite views on the horizontal growth are defined as the compact urban form which encourages the walking and minimizes the environment degradation, encourages the social, economic and land use diversity to contrast homogeneity and uniformity, connects land uses, has high quality public spaces which create opportunities for interaction and interchange, provide fair access to goods, 
services and facilities and protect human and environment health (Talen, 2013). In designing the rural to urban transects, a wide environmental range from rural to urban is the basis of habitat features structure which includes land, building, land use, street and all other physical elements of human habitat, finding a suitable space allocation from elements which form the human habitat. Rural elements should look for their position in the rural places, while urban elements are found in urban areas. Transect is designed to strengthen the integrity of each inclusive environment and can be used as an alternative for conventional zoning systems (Talen et al., 2007). Seven basic principles of neighborhood units' traditional development on their consistency with smart urban growth are as follows:

Connected streets pattern: a transport network is far more efficient than a case that consists of stalemate passages and few connector streets. More connection allows traffic to be distributed instead of concentration in one place and there are more options of routes and increases the time of response for emergency services and empowers the transportation.

(1) Inclusion of parks and open spaces in neighborhood units design to evaluate the environmental problems effectively.

(2) Compact design of a site results in the preservation of land surfaces and investment and maintenance costs of infrastructures.

(3) Integration of consistent land use: Such as a business in smaller scale and administrative levels with neighborhood habitats help the creation of job opportunities and services in the local level and finally decreasing the number of trips which requires cars in a conventional suburb level.

(4) Designing low traffic streets: Narrow streets are combined with marginal parking and it showed that it decreases the cars speed. Narrow streets promote the walkability through decreasing the effort of pedestrians and required time to cross the street. Marginal parking as a safe barrier protects travelers from parked cars against the current traffic. stop signs in regular intersections and other traffic reducing measures such as speed controllers and speed tables can also be combined and decline the traffic to the favorable speeds by pedestrians.

(5) Cost saving: Traditional development of neighborhood units creates privileges for those who pay taxes as well as local government that should balance tax revenues and service costs. Many research show that compact forms with development of mixed uses not only decrease the land consumption, but also decline the creation and maintenance costs of conventional separations.

(6) Popular traffic design: Connected patterns of streets, a combination of uses, a wide variety of home and congestion of habitats with general concept of creation of a walkable neighborhood is inherently supporter of public transport, subway or bus. Since efficiency of a public transport is a key factor in the smart growth, conventional development of neighborhood units is considered as a main concept of smart growth (Atlanta, 2005).

Neighborhood unit is the fundamental progress of human habitat throughout the history which is separated just by 60 years deviation that is now called horizontal growth of the suburb. Smart growth of a region can be measured using neighborhood unit structure strength (neighborhood unit principles) (Duani et al., 2012). Local communities of smart growth first include neighborhood units that meet the daily needs of residents in a suitable walking distance. The most complete neighborhood units provide walking paths to school, recreation centers, open spaces and stores. While neighborhood units include wide range of houses, creation of higher density is encouraged (Ibid). 


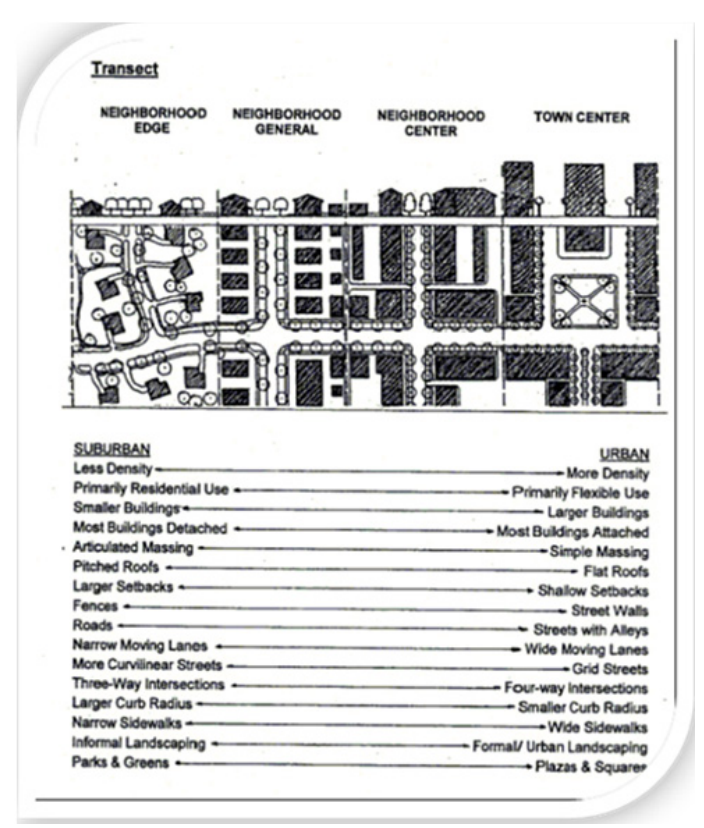

Figure 1. Traditional neighborhoods indices in transect design

A neighborhood unit design should try to create a balanced mix of different uses such as living, work, shopping, recreation and public uses. Such neighborhood units decline the undesired effect of traffic along with services and infrastructures costs. For various reasons, a healthy neighborhood unit has a wide range of habitation: because valid social networks depend on wide range of income and age and affordable habitation provide environmental health concentration and it helps builders to have access and attract all parts of market faster. All neighborhood units need to have retail space, the size of this space is depends on the neighborhood unit size and its density in relation to transport. Moreover, the units should have urban school sites, supportive services of local outdoors and residential density. According to definition, Neighborhood units are created in the pedestrian scale. A neighborhood unit is zoning not based on land use and on the basis of adaptable structural in which form-based regulations are implemented (Ibid). Neighborhood unit size matches a five minute walking or walkable range. This structure place most families in a short walking to a center with various uses (neighborhood unit size). Every neighborhood unit is defined first by its center and then by its edge. The center of neighborhood unit should contain a public space such as plaza, square or greenbelt depending on local culture. Edge is usually boulevards or parkways where there is traffic (organizing the neighborhood unit). Smart growth regulations which are based on buildings configuration, should replace the conventional zoning which is based on land use. Tall buildings are located among tall buildings; medium buildings are among medium buildings. Streets except rare cases must be symmetric with similar buildings on their sides and zoning changes should be made In the middle of blocks along the back plots where. So that homogenous street landscape can be obtained from non-uniform blocks. (Form-based zoning) a permeable street network is the result of small blocks presence. Kane Jacobs observed that the most walkable parts of small and large cities are located in places with smallest blocks. Surrounding area of available blocks in new neighborhood units must typically have 300-400 meters length (blocks size). Created passages typically have narrow path, facilities for bicycle movement, marginal parking, adequate sidewalks, continuous trees, street furniture, street lights and supportive frontages. When streets became pleasant sites, probably more people will leave their cars in their homes. Sidewalks and passages can be used to strengthen a pedestrian network with 3-6 m width. Sidewalks create some cross-cuts between long blocks in residential neighborhood units to create an efficient network for pedestrians. Public domain (passages and sidewalks) are shaped by private surrounding buildings. Place and configuration of a public domain helps its safety, spatial definition, performance and visual attraction to create a public domain, establishment of private buildings should be in a way that can surround the street space easily and view of buildings can array relatively close together (Ibid). People can less feel the need for private cars through creating a better balance in car use and availability of more walkable streets. Areas equipped with complete transit system should compel builders to provide maximum parking instead of minimum parking (Ibid). Ground level parking lots should be located in the block centers to be hidden from view by residential buildings. Most of the zoning standards control buildings through retreats, arrangement of buildings on the plot and occupied area by a building (Ibid). Regions with 
public transit system are the most appropriate areas to locate tall buildings. Mixed -use buildings are so flexible and include a ground level commercial floor on which one or several residential or work spaces are built. Apartment houses are generally built toward the center of neighborhood unit, but are compatible with single-family homes. A residential-commercial building which is also called flexible house is a single-family home which is considered as workplace too. Such buildings are built near the neighborhood unit center and establish a perfect transition from commercial buildings to homes. Villas well known as single-story homes are independent buildings which are built on narrow lands with 75 to $135 \mathrm{~m}$ residential space. Such houses can located as small clusters throughout a neighborhood unit (Duany, 2012).

\section{Results}

All mentioned indices in the smart growth guide and transect design of smart growth code are categorized as follows and are gathered in a table to facilitate adapting the urban smart growth indices code. Given the importance of criteria weights and their effectiveness level, the diagram of categorizing the smart growth indices are arranged in the following hierarchical diagram:

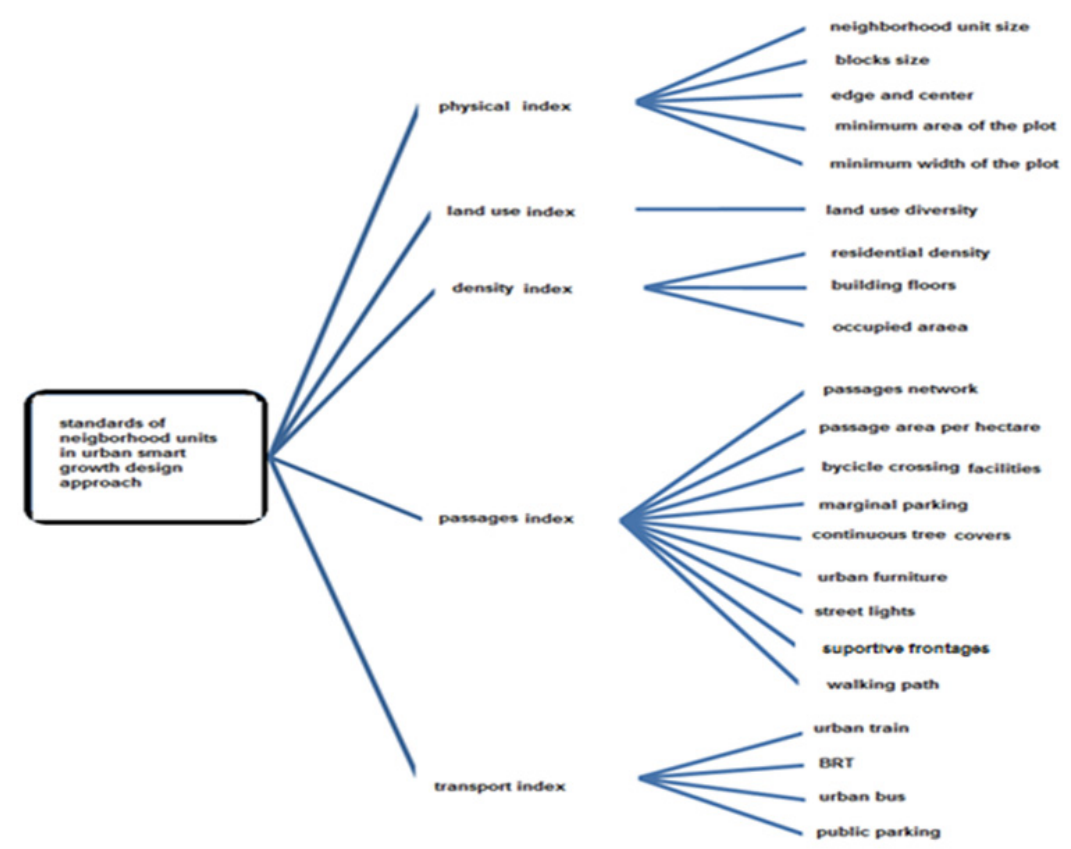

Figure 2. Neighborhood unit indices in urban smart growth

The first levels of 5 main indices are weighted using paired comparisons of AHP model. Weighting is performed based on the index importance in planning and designing process of urban areas:

Table 1. Main index matrix (level 1)

\begin{tabular}{cccccccc}
\hline $\begin{array}{c}\text { Main } \\
\text { indices }\end{array}$ & $\begin{array}{c}\text { Physical } \\
\text { index }\end{array}$ & $\begin{array}{c}\text { Land use } \\
\text { index }\end{array}$ & $\begin{array}{c}\text { Density } \\
\text { index }\end{array}$ & $\begin{array}{c}\text { Passages } \\
\text { index }\end{array}$ & $\begin{array}{c}\text { Transport } \\
\text { index }\end{array}$ & $\begin{array}{c}\text { Geometric } \\
\text { mean }\end{array}$ & $\begin{array}{c}\text { Normal } \\
\text { weight }\end{array}$ \\
\hline $\begin{array}{c}\text { Physical } \\
\text { index }\end{array}$ & 1 & 4 & 6 & 2 & 3 & 2.702 & 0.427 \\
$\begin{array}{c}\text { Physical } \\
\text { index }\end{array}$ & 1.4 & 1 & 2 & 1.3 & 1.2 & 0.608 & 0.096 \\
$\begin{array}{c}\text { Physical } \\
\text { index }\end{array}$ & 1.6 & 1.2 & 1 & 1.4 & 1.3 & 0.37 & 0.059 \\
$\begin{array}{c}\text { Physical } \\
\text { index }\end{array}$ & 1.6 & 3 & 4 & 1 & 2 & 1.644 & 0.26 \\
$\begin{array}{c}\text { Physical } \\
\text { index }\end{array}$ & 1.3 & 2 & 3 & 1.2 & 1 & 1 & 0.158 \\
\hline
\end{tabular}

Note. Incompatibility rate $=0.011$. 
Then, subsidiary indices in every set are weighed and regulated in separate matrixes, respectively.

Table 2. Sub-criteria index (physical index)

\begin{tabular}{clllllll}
\hline Physical indices & Neighborhood size & Blocks size & Primary center & Plot area & Plot width & Geometric mean & Normal weight \\
\hline Neighborhood size & 1 & 1.2 & 2 & 3 & 4 & 1.644 & 0.263 \\
Neighborhood size & 2 & 11 & 3 & 4 & 5 & 2.605 & 0.417 \\
Neighborhood size & 1.2 & 1.3 & 1 & 2 & 3 & 1 & 0.16 \\
Neighborhood size & 1.3 & 1.4 & 1.2 & 1 & 2 & 0.608 & 0.097 \\
Neighborhood size & 1.4 & 1.5 & 1.3 & 1.2 & 1 & 0.384 & 0.061 \\
\hline Note. Inche
\end{tabular}

Note. Incompatibility index $=0.015$.

Table 3. Sub-criteria matrix (density index)

\begin{tabular}{llllll}
\hline \multicolumn{1}{c}{ Density index } & density & Number of floors & Occupied area & Geometric mean & Normal weight \\
\hline Density & 1 & 1.2 & 2 & 1 & 0.286 \\
Number of floors & 2 & 1 & 4 & 2 & 0.571 \\
Occupied area & 1.2 & 1.4 & 1 & 0.5 & 0.143 \\
\hline
\end{tabular}

Note. Incompatibility rate $=0.012$.

Table 4. Sub-criteria matrix (transport index)

\begin{tabular}{cllllll}
\hline Transport index & Urban train & BRT & Urban bus & Public parking & Geometric mean & Normal weight \\
\hline Urban train & 1 & 4 & 2 & 3 & 2.213 & 0.447 \\
Urban train & 1.4 & 1 & 1.3 & 1.2 & 0.452 & 0.095 \\
Urban train & 1.2 & 3 & 1 & 2 & 1.316 & 0.277 \\
Urban train & 1.3 & 2 & 1.2 & 1 & 0.76 & 0.16 \\
\hline
\end{tabular}

Note. Incompatibility rate $=0.017$.

Table 5. Sub- criteria matrix (passages index)

\begin{tabular}{|c|c|c|c|c|c|c|c|c|c|c|c|}
\hline 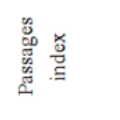 & 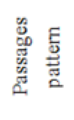 & 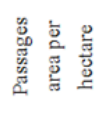 & 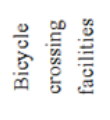 & 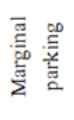 & 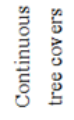 & 超总 & 总 & 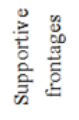 & 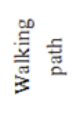 & 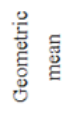 & 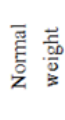 \\
\hline $\begin{array}{l}\text { Passages } \\
\text { pattern }\end{array}$ & 1 & 2 & 4 & 4 & 6 & 6 & 6 & 5 & 3 & 3.608 & 0.301 \\
\hline $\begin{array}{l}\text { Passages } \\
\text { area per } \\
\text { hectare }\end{array}$ & 1.2 & 1 & 3 & 3 & 5 & 5 & 5 & 4 & 2 & 2.546 & 0.212 \\
\hline $\begin{array}{l}\text { Bicycle } \\
\text { crossing } \\
\text { facilities }\end{array}$ & 1.4 & 1.3 & 1 & 1 & 3 & 3 & 3 & 2 & 1.2 & 1.084 & 0.09 \\
\hline $\begin{array}{l}\text { Marginal } \\
\text { parking }\end{array}$ & 1.4 & 1.3 & 1 & 1 & 3 & 3 & 3 & 2 & 1.2 & 1.084 & 0.09 \\
\hline $\begin{array}{l}\text { Continuous } \\
\text { tree covers }\end{array}$ & 1.6 & 1.5 & 1.3 & 1.3 & 1 & 1 & 1 & 1.2 & 1.4 & 0.426 & 0.036 \\
\hline $\begin{array}{l}\text { Urban } \\
\text { furniture }\end{array}$ & 1.6 & 1.5 & 1.3 & 1.3 & 1 & 1 & 1 & 1.2 & 1.4 & 0.426 & 0.036 \\
\hline Street lights & 1.6 & 1.5 & 1.3 & 1.3 & 1 & 1 & 1 & 1.2 & 1.4 & 0.426 & 0.036 \\
\hline $\begin{array}{l}\text { Supportive } \\
\text { frontages }\end{array}$ & 1.5 & 1.4 & 1.2 & 1.2 & 2 & 2 & 2 & 1 & 1.3 & 0.685 & 0.057 \\
\hline $\begin{array}{l}\text { Walking } \\
\text { path }\end{array}$ & 1.3 & 1.2 & 2 & 2 & 4 & 4 & 4 & 3 & 1 & 1.714 & 0.143 \\
\hline
\end{tabular}

Criteria and indices of urban smart growth are determined and measured based on mentioned described standards and documentations. These quantitative values which are used as research final criteria for decision making are first ranked and then are derived from consultant's report documentations for local project of Qarani neighborhood of Mashhad. 
Table 6. Primary stage of ranking the indices

\begin{tabular}{|c|c|c|c|c|}
\hline \multicolumn{2}{|c|}{$\begin{array}{l}\text { Neighborhood units criteria in urban smart growth } \\
\text { design approach (Physical index) }\end{array}$} & Low rank & High rank & Qarani neighborhood \\
\hline Neighborhood unit size & $80-160$ acre & $80-160$ & $120-130$ & equivalent to 101 acre, $412250 \mathrm{~m}^{2}$ \\
\hline Blocks size & $150-400 \mathrm{~m}$ perimeter & $500-600$ & $<100 \mathrm{~m}$ & Max: $280 \min : 120$ \\
\hline \multicolumn{2}{|c|}{ Center and edge center: public area or green belt } & Tall building & Public space & Green belt, religious, training space \\
\hline \multicolumn{2}{|c|}{ Edge: boulevard or parkway } & $\begin{array}{l}\text { Residential } \\
\text { Singles-home }\end{array}$ & boulevard & wide street and path \\
\hline \multicolumn{2}{|c|}{$\begin{array}{l}\text { Minimum area of plot single- at least } 130 \mathrm{~m}^{2} \\
\text { Complex - at least } 450 \mathrm{~m}^{2}\end{array}$} & & & $\begin{array}{l}\text { At least } 100 \mathrm{~m}^{2} \text {, single home, } \\
\text { encouraging policy, at least } 540 \mathrm{~m}^{2} \\
\text { complex }\end{array}$ \\
\hline \multicolumn{2}{|c|}{$\begin{array}{l}\text { Minimum and maximum width of plot min: } 5.5 \mathrm{~m} \text { max: } \\
210 \mathrm{~m}\end{array}$} & & & No regulations \\
\hline \multicolumn{2}{|c|}{$\begin{array}{l}\text { Land use diversity: residential, commercial, greenbelt, } \\
\text { leisure time, work space (Land use index) }\end{array}$} & Single use & 6 Land uses & $\begin{array}{l}\text { Residential, mixed } \\
\text { residential-commercial, greenbelt, } \\
\text { training, religious space }\end{array}$ \\
\hline \multicolumn{2}{|c|}{$\begin{array}{l}\text { Residential dens (Density index) } \\
24 \text { unit per acre equivalent to } 6 \text { units per } 1000 \mathrm{~m}^{2}\end{array}$} & $<2$ & $>6$ & $\begin{array}{l}23 \text { units per acre equivalent to } 2715 \text { units } \\
\text { throughout neighborhood }\end{array}$ \\
\hline \multicolumn{2}{|c|}{ Building floors: min: 3 and max: 8 floors in T6 zone } & 1 floor & 8 floors & $\begin{array}{l}\text { min density: } 200 \% \text { equivalent to } 4 \text { floors } \\
\text { and } \max 300 \%: 6 \text { floors }\end{array}$ \\
\hline \multicolumn{2}{|l|}{ Occupied area } & $40 \%$ & $90 \%$ & $60 \%$ \\
\hline \multicolumn{2}{|c|}{$\begin{array}{l}\text { Passages network connected streets pattern (Passages } \\
\text { index) }\end{array}$} & Deadlock $50 \%$ & $\begin{array}{l}\text { no } \\
\text { deadlock }\end{array}$ & Plaid connected streets pattern \\
\hline \multicolumn{2}{|c|}{ Passages design passages area per hectare } & $60 \mathrm{~m}$ & $300 \mathrm{~m}$ & $\begin{array}{l}\text { Above } 300 \mathrm{~m} \text { per hectare }(13000 \mathrm{~m} \\
\text { throughout the neighborhood) }\end{array}$ \\
\hline \multicolumn{2}{|l|}{ Bicycle crossing facilities } & $<15 \%$ & $>85 \%$ & More than $30 \mathrm{~km}$ just in main passages \\
\hline \multicolumn{2}{|l|}{ Marginal parking } & $<15 \%$ & $>85 \%$ & In $20 \%$ of passages \\
\hline \multicolumn{2}{|l|}{ Continuous tree covers } & $<15 \%$ & $>85 \%$ & In all passages, no detail \\
\hline \multicolumn{2}{|l|}{ Urban furniture } & $<15 \%$ & $>85 \%$ & No detail \\
\hline \multicolumn{2}{|l|}{ Street lights } & $<15 \%$ & $>85 \%$ & No detail \\
\hline \multicolumn{2}{|l|}{ Supportive frontages } & $<15 \%$ & $>85 \%$ & No detail \\
\hline \multicolumn{2}{|l|}{ Walking path } & $\begin{array}{l}3-6 \mathrm{~m} \text { width } \\
(\mathrm{T} 5-\mathrm{T} 6)\end{array}$ & & $\begin{array}{l}\text { Minimum width of } 1.75 \text { in } 12 \mathrm{~m} \text { paths } \\
\text { and Maximum width of } 4.5 \mathrm{~m} \text { in } 45 \mathrm{~m} \\
\text { paths }\end{array}$ \\
\hline \multicolumn{2}{|c|}{$\begin{array}{l}\text { Urban train number of stations } \\
\text { BRT number of stations } \\
\text { Urban bus number of stations } \\
\text { Public parking establishment site (Transport index) }\end{array}$} & $\begin{array}{l}\text { No station } \\
\text { No station } \\
\text { No station } \\
\text { In edges }\end{array}$ & $\begin{array}{l}\quad \begin{array}{l}>4 \\
\quad>4\end{array} \\
\quad>4\end{array}$ & $\begin{array}{l}\text { Qarani-Karimi line, with } 2 \text { stations } \\
\text { Qarani-Karimi line, with } 3 \text { stations } \\
4 \text { bus lines and } 12 \text { stations } \\
6 \text { public parking- one hectare }\end{array}$ \\
\hline
\end{tabular}

All required criteria and indices for compliance of urban smart growth in the local project of Qarani neighborhood in Mashhad are derived based on documentations presented in the consultant report and a score from 0 to 100 are considered for every criteria: 
Table 7. Scoring the smart growth indices

\begin{tabular}{|c|c|c|c|c|c|c|c|}
\hline \multicolumn{2}{|c|}{$\begin{array}{l}\text { regulations of neighborhood units in } \\
\text { urban smart growth design approach }\end{array}$} & \multirow{2}{*}{$\begin{array}{l}\text { Incompatibility } \\
\begin{array}{l}0 \\
<80>160\end{array}\end{array}$} & \multirow{2}{*}{$\begin{array}{l}\text { very poor } \\
20 \\
80-90 \\
150-160\end{array}$} & \multirow{2}{*}{$\begin{array}{l}\text { poor } \\
40 \\
140-150 \\
90-100\end{array}$} & \multirow{2}{*}{$\begin{array}{l}\text { moderate } \\
60 \\
130-140 \\
100-110\end{array}$} & \multirow{2}{*}{$\begin{array}{l}\begin{array}{l}\text { relatively } \\
\text { well } \\
80\end{array} \\
130-135 \\
110-120\end{array}$} & \multirow{2}{*}{$\begin{array}{l}\text { completely } \\
\text { compatible } \\
100 \\
120-130\end{array}$} \\
\hline $\begin{array}{l}\text { Neighborhood } \\
\text { unit size } \\
\text { (Physical index) }\end{array}$ & $80-160$ acre & & & & & & \\
\hline $\begin{array}{l}\text { Blocks size } \\
\text { (physical index) }\end{array}$ & $\begin{array}{l}150-400 \mathrm{~m} \\
\text { perimeter }\end{array}$ & $>400$ & $350-400$ & $300-350$ & $250-300$ & $200-250$ & $150-200$ \\
\hline $\begin{array}{l}\text { Center and edge } \\
\text { (Physical index) }\end{array}$ & $\begin{array}{l}\text { Center: public } \\
\text { space or greenbelt }\end{array}$ & $\begin{array}{l}\text { residential(tall } \\
\text { buildings) }\end{array}$ & $\begin{array}{l}\text { single-home } \\
\text { residential } \\
\text { public space }\end{array}$ & $\begin{array}{l}\text { sanitary-training } \\
\text { parking }\end{array}$ & $\begin{array}{l}\text { institutional- } \\
\text { urban use } \\
\text { institutional- } \\
\text { urban use }\end{array}$ & greenbelt & $\begin{array}{l}\text { public space } \\
\text { boulevard-p } \\
\text { arkway }\end{array}$ \\
\hline $\begin{array}{l}\text { Minimum plot } \\
\text { area (Physical } \\
\text { index) }\end{array}$ & $\begin{array}{l}\text { Single: } 130 \mathrm{~m} 2- \\
\text { complex: } 540\end{array}$ & no policy & & $\begin{array}{l}\text { without minimum } \\
\text { and......encourage } \\
\text { policy }\end{array}$ & $\begin{array}{l}\text { encouraging } \\
\text { and minimum } \\
\text { policy }\end{array}$ & & $\begin{array}{l}\text { smart } \\
\text { criteria }\end{array}$ \\
\hline $\begin{array}{l}\text { Min and max } \\
\text { width of plot } \\
\text { (Physical index) }\end{array}$ & $\begin{array}{l}\mathrm{m} 2 \\
5.5-210\end{array}$ & no policy & & & & & $\begin{array}{l}\text { smart } \\
\text { criteria }\end{array}$ \\
\hline $\begin{array}{l}\text { Land use } \\
\text { diversity (Land } \\
\text { use index) }\end{array}$ & $\begin{array}{l}\text { Residential-comm } \\
\text { ercial, greenbelt, } \\
\text { leisure time, work } \\
\text { space }\end{array}$ & single use & & & & & $\begin{array}{l}\text { diversity of } \\
6 \text { land use } \\
\text { types }\end{array}$ \\
\hline \multirow[t]{3}{*}{$\begin{array}{l}\text { Residential } \\
\text { density (Density } \\
\text { index) }\end{array}$} & $\begin{array}{l}24 \text { units per acre, } \\
\text { equivalent to } 6 \\
\text { units per } 1000 \\
\mathrm{~m}^{2}\end{array}$ & $<2$ & & & & & $>6$ \\
\hline & $\begin{array}{l}\text { building floors: } \\
\text { min:3 - max: } 8 \\
\text { floors in T6 zone }\end{array}$ & one floor & $2 \& 3$ & $3 \& 4$ & $4 \& 5$ & $6 \& 7$ & 8 \\
\hline & Occupied area & $40 \%$ & $50 \%$ & $60 \%$ & $70 \%$ & $80 \%$ & $90 \%$ \\
\hline $\begin{array}{l}\text { Passages } \\
\text { network } \\
\text { (Passages index) }\end{array}$ & $\begin{array}{l}\text { Connected streets } \\
\text { pattern }\end{array}$ & $50 \%$ deadlock & $40 \%$ deadlock & $30 \%$ deadlock & $20 \%$ deadlock & $10 \%$ deadlock & no deadlock \\
\hline \multirow[t]{3}{*}{$\begin{array}{l}\text { Passages design } \\
\text { (Passages index) }\end{array}$} & $\begin{array}{l}\text { Passage area per } \\
\text { hectare }\end{array}$ & $\begin{array}{l}<100 \mathrm{~m} \text { per } \\
\text { hectare }\end{array}$ & $\begin{array}{l}100-150 \mathrm{~m} \\
\text { per ha }\end{array}$ & $150-200 \mathrm{~m}$ per ha & $\begin{array}{l}200-250 \mathrm{~m} \\
\text { per ha }\end{array}$ & $\begin{array}{l}250-300 \mathrm{~m} \\
\text { per ha }\end{array}$ & $\begin{array}{l}>300 \mathrm{mper} \\
\text { ha }\end{array}$ \\
\hline & $\begin{array}{l}\text { Bicycle crossing } \\
\text { facilities }\end{array}$ & no facilities & $0-20 \%$ & $20-40 \%$ & $40-60 \%$ & $60-80 \%$ & $>80 \%$ \\
\hline & Marginal parking & no facilities & $0-20 \%$ & $20-40 \%$ & $40-60 \%$ & $60-80 \%$ & $>80 \%$ \\
\hline
\end{tabular}




\begin{tabular}{|c|c|c|c|c|c|c|c|}
\hline & $\begin{array}{l}\text { Continuous tree } \\
\text { covers }\end{array}$ & no facilities & $0-20 \%$ & $20-40 \%$ & $40-60 \%$ & $60-80 \%$ & $>80 \%$ \\
\hline & Urban furniture & no facilities & $0-20 \%$ & $20-40 \%$ & $40-60 \%$ & $60-80 \%$ & $>80 \%$ \\
\hline & Street lights & no facilities & $0-20 \%$ & $20-40 \%$ & $40-60 \%$ & $60-80 \%$ & $>80 \%$ \\
\hline & $\begin{array}{l}\text { Supportive } \\
\text { frontages }\end{array}$ & no facilities & $0-20 \%$ & $20-40 \%$ & $40-60 \%$ & $60-80 \%$ & $>80 \%$ \\
\hline $\begin{array}{l}\text { Walking paths } \\
\text { (Passages index) }\end{array}$ & $\begin{array}{l}\text { 3-6 m width } \\
\text { (T5-T6) }\end{array}$ & no walking path & & & & & $\begin{array}{l}\text { smart } \\
\text { criteria }\end{array}$ \\
\hline (Transport index) & $\begin{array}{l}\text { Number of } \\
\text { stations }\end{array}$ & 0 & 1 & 2 & 3 & 4 & $>4$ \\
\hline Urban train & number of stations & 0 & 1 & 2 & 3 & 4 & $>4$ \\
\hline BRT & number of stations & no parking & 1 & 2 & 3 & 4 & $>4$ \\
\hline $\begin{array}{l}\text { Urban bus } \\
\text { Public parking }\end{array}$ & $\begin{array}{l}\text { establishment } \\
\text { place }\end{array}$ & & $\begin{array}{l}\text { parking with } \\
\text { unsuitable } \\
\text { establishment }\end{array}$ & & & & $\begin{array}{l}\text { parking } \\
\text { inside the } \\
\text { blocks }\end{array}$ \\
\hline
\end{tabular}

A guide or criterion is regulated to evaluate and rank neighborhoods and urban areas compared with smart growth indices after gathering and scrutinizing indices based on documentations presented in the related reference. Local project of Qarani and Horeameli streets neighborhood was notified to consultant by Mashhad municipality. The aim was to study hidden potentials and capabilities of the neighborhood in relation to its position in the city and presenting economic and operational strategies through preparation of development and organizing the neighborhood with urban design approach. the local project of Qarani and Horeameli streets neighborhood was prepared in a place with almost 62 hectare area located in the west part of Imam Reza holy shrine in Mashhad in 2013 (Mehrazan, 2013).

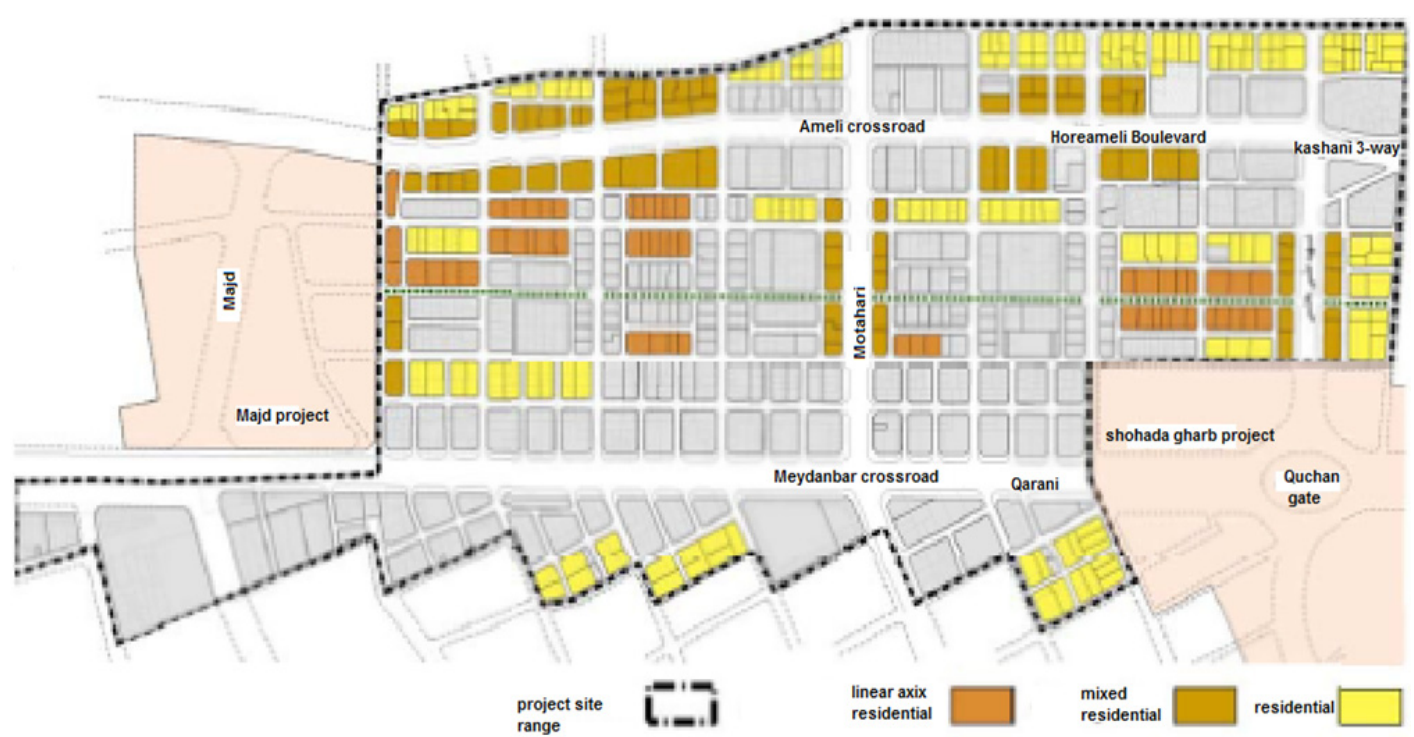

Figure 3. Recommended land use of the Qarani neighborhood local project in Mashhad (Mehrazan, 2013) 
Final results of these studies are preparation of the smart growth evaluation table and determining the compatibility degree of Qarani neighborhood unit local project with urban smart growth as presented in the following matrix:

Table 8. Final table of scores and total compatibility degree

\begin{tabular}{|c|c|c|c|c|c|c|c|}
\hline \multirow{2}{*}{$\begin{array}{c}\text { Indices } \\
\\
\text { Physical } \\
\text { index }\end{array}$} & \multicolumn{2}{|r|}{ Data } & \multirow{2}{*}{$\begin{array}{l}\begin{array}{c}\text { Main } \\
\text { index } \\
\text { weight }\end{array} \\
0.427\end{array}$} & \multirow{2}{*}{$\begin{array}{c}\text { Subsidiary } \\
\text { index weight } \\
0.263\end{array}$} & \multirow{2}{*}{$\begin{array}{c}\text { Total } \\
\text { weight } \\
0.1123\end{array}$} & \multirow{2}{*}{$\begin{array}{c}\text { Score (from } \\
100 \text { total } \\
\text { scores) }\end{array}$} & \multirow{2}{*}{$\begin{array}{r}\text { Score * } \\
\text { weight } \\
6.74\end{array}$} \\
\hline & $\begin{array}{l}\text { Neighborhood } \\
\text { unit size }\end{array}$ & $80-16-$ acre & & & & & \\
\hline & Blocks size & $150-400 \mathrm{~m}$ perimeter & & 0.417 & 0.1781 & 100 & 17.81 \\
\hline & Center and edge & $\begin{array}{c}\text { Center: public space or greenbelt } \\
\text { Edge: }\end{array}$ & & 0.16 & 0.0683 & 80 & 5.46 \\
\hline & & boulevard or parkway & & & & & 2.48 \\
\hline & $\begin{array}{l}\text { Minimum plot } \\
\text { area }\end{array}$ & Single: $130 \mathrm{~m} 2$ - complex: 540 & & 0.097 & 0.0414 & 60 & 0 \\
\hline & $\begin{array}{l}\text { Min and max } \\
\text { width of plot }\end{array}$ & $\begin{array}{c}\mathrm{m} 2 \\
5.5-210\end{array}$ & & 0.061 & 0.026 & 0 & 9.6 \\
\hline $\begin{array}{l}\text { Land use } \\
\text { index }\end{array}$ & $\begin{array}{l}\text { Land use } \\
\text { diversity }\end{array}$ & $\begin{array}{l}\text { Residential-commercial, } \\
\text { greenbelt, leisure time, work } \\
\text { space }\end{array}$ & 0.096 & 1 & 0.096 & 100 & 1.69 \\
\hline \multirow[t]{3}{*}{$\begin{array}{l}\text { Density } \\
\text { index }\end{array}$} & $\begin{array}{l}\text { Residential } \\
\text { density }\end{array}$ & $\begin{array}{l}24 \text { units per acre, equivalent to } 6 \\
\text { units per } 1000 \\
\mathrm{~m} 2\end{array}$ & 0.059 & 0.286 & 0.169 & 100 & 2.69 \\
\hline & & $\begin{array}{l}\text { building floors : } \min : 3-\max : 8 \\
\text { floors in } \mathrm{T} 6 \text { zone }\end{array}$ & & 0.571 & 0.0337 & 80 & 0.34 \\
\hline & & Occupied area & & 0.143 & 0.0084 & 40 & 0.34 \\
\hline \multirow[t]{8}{*}{$\begin{array}{l}\text { Passages } \\
\text { index }\end{array}$} & $\begin{array}{c}\text { Passages } \\
\text { network }\end{array}$ & Connected streets pattern & 0.26 & 0.301 & 0.0783 & 100 & 7.83 \\
\hline & \multirow[t]{7}{*}{ Passages design } & Passage area per hectare & & 0.212 & 0.0551 & 100 & 5.51 \\
\hline & & Bicycle crossing facilities & & 0.09 & 0.0234 & 20 & 0.47 \\
\hline & & Marginal parking & & 0.09 & 0.0234 & 40 & 0.94 \\
\hline & & Continuous tree covers & & 0.036 & 0.0094 & 80 & 0.75 \\
\hline & & Urban furniture & & 0.036 & 0.0094 & 0 & 0 \\
\hline & & Street lights & & 0.036 & 0.0094 & 0 & 0 \\
\hline & & $\begin{array}{l}\text { Supportive frontages } \\
\text { 3-6 m width (T5-T6) }\end{array}$ & & $\begin{array}{l}0.057 \\
0.143\end{array}$ & $\begin{array}{c}0.0148 \\
0.372\end{array}$ & $\begin{array}{c}0 \\
80\end{array}$ & $\begin{array}{c}0 \\
2.98\end{array}$ \\
\hline $\begin{array}{l}\text { Transport } \\
\text { index }\end{array}$ & $\begin{array}{c}\text { Urban train } \\
\text { BRT } \\
\text { Urban bus } \\
\text { Public parking }\end{array}$ & Number of stations & 0.158 & $\begin{array}{c}0.447 \\
0.095 \\
0.277 \\
0.16\end{array}$ & $\begin{array}{l}0.0706 \\
0.015 \\
0.0438 \\
0.0253\end{array}$ & $\begin{array}{l}40 \\
60 \\
80 \\
80\end{array}$ & $\begin{array}{c}282 \\
0.9 \\
3.5 \\
2.02\end{array}$ \\
\hline & & & Sum. & & 0.9962 & & 74.53 \\
\hline
\end{tabular}

In table (8), it can be seen that the Qarani neighborhood acquires 74.53 sores of total 100 scores after taking into 
account the indices weight and scoring the urban smart growth. This score shows relatively good compatibility with the urban smart growth approach.

\section{Hypothesis Testing}

To ensure the statistical accuracy of the above mentioned process, scoring stages are followed one more time without using AHP method. Here, we use SPSS to conduct the One-Sample t-Test.

$\mathrm{H} 0$ is defined as: Mean $\geq 50$ or mean scores of the smart growth is $\geq 50$ in the study area.

Consequently, H1 means that the smart growth score is less than 50 that indicates that the urban smart growth approach is not considered in the given region project. In table (8), score column that represents the compatibility with the smart growth approach, was prepared before applying the weights of AHP method. These scores are processed in the SPSS software and the results are as follows:

Table 9. The results of One-Sample t-Test in SPSS software

\begin{tabular}{|c|c|c|c|c|}
\hline & $\mathrm{N}$ & Mean & Std. Deviation & Std. Error Me \\
\hline Valt & 22 & 59.0909 & 36.24114 & 7.72664 \\
\hline
\end{tabular}

The mean score is also higher than 50 (59.09) and represents that results of Qarani neighborhood unit reconstruction indices are close to the smart growth approach.

Table 10. The results of significance of One-Sample t-Test in SPSS software

\begin{tabular}{|c|c|c|c|c|c|c|}
\hline \multirow[b]{4}{*}{ Value } & \multicolumn{6}{|c|}{ Test Value $=50$} \\
\hline & \multirow{2}{*}{$\mathrm{t}$} & \multirow{2}{*}{$\mathrm{df}$} & \multirow{2}{*}{ Sig. (2-tailed) } & \multirow{2}{*}{ Mean Difference } & \multicolumn{2}{|c|}{$95 \%$ Confidence Interval of the Difference } \\
\hline & & & & & Lower & Upper \\
\hline & 1.177 & 21 & .253 & 9.09091 & -6.9775 & 25.1593 \\
\hline
\end{tabular}

By entering the numerical test value (test value=50), confidence interval values includes negative quantities $(-6.75)$ which shows the uncertainty of compatibility of smart growth indices that are higher than $50 \%$.

Table 11. The results of significance of One-Sample t-Test in SPSS software

\begin{tabular}{ccccccc}
\hline & \multicolumn{1}{c}{ t } & \multicolumn{4}{c}{ Test Value $=0$} \\
\cline { 2 - 7 } Value & 7.648 & 21 & Sig. (2-tailed) & Mean Difference & $\begin{array}{c}\text { 95\% Confidence Interval of the Difference } \\
\text { Lower }\end{array}$ & Upper \\
\cline { 2 - 7 } & & & .000 & 59.09091 & 43.0225 & 75.1593 \\
\hline
\end{tabular}

By entering the numerical test value (test value=0) confidence interval values with $95 \%$ of probability are between 43-75 which is an acceptable range in which Qarani local project indices are close to the smart growth criteria.

\section{Conclusion}

This study aims to makes it possible to compare criteria and indices of urban smart growth with local projects and reconstruction of urban neighborhoods. In this study, AHP and hypothesis test for mean as a credible statistical process to compare qualitative indices of urban planning and design were used in this study. All scores and comparisons of designing criteria were derived from consultant documentations related to the Qarani neighborhood and the conventional scoring range was used after being in a quantitative form. Considering the similarity of more than $50 \%$ of indices results showed relative compatibility of new approach of Qaran neighborhood designing with the urban smart growth. The compatibility increases as score of the indices table increases from $50 \%$ to $100 \%$. Given the positive achievements of urban smart growth in horizontal growth decrease and social interactions increase and environment degradation prevention, orientation of urban planning, designing and reconstruction of worn-out urban texture of neighborhood units toward this approach can decrease many disorders of the urban communities. Tendency of urban design methods toward smart growth have had increasing effect on decreasing the difficulties in metropolises of developing countries. Findings indicate the relative compatibility of smart growth in new designs presented by urban management of Mashhad as a 
Petropolis. However, more efforts and studies are required to obtain better compatibility score and desired results.

\section{References}

Andalib, A. (2008). Notes on worn-out texture reconstruction, 22. Reypoor Press, Tehran.

Atlanta Commission Regional Traditional Neighborhood Developement Implementation. (2005). Atlanta : ARC.

Bandarabad, A. (2010). City form and urbanism: Investigating the effect of urbanism principles on the shape of Tehran city, 9. Manzar Press, Tehran.

Building and Housing Research Center. (2007). National Regulations of Building, 1. Tehran.

Duany, \& Plater-Zyberk, S. (2013). Central Smartcode, 1.

Duany, A., Speck,J., \& Lydon, M. (2012). Smart growth guide. Guilan University Press, Rasht.

Edwards, M. M., \& Haines, A. (2007). Evaluating smart growth implication for small communities. Journal of Planning Education and Research, 55.

Eynifar, A. (2007). Main role of primary general patterns in designing the contemporary residential neighborhoods. Fine Art Journal, 32, 450.

Falamaki, M. M. (2005). Urban renovation and rehabilitation, 45-46. SAMT Press, Tehran.

Farnahad Consulting Engineers Company. (2007). Development and reconstruction of Mashhad Metropolis report. Ministry of Housing and Urban Development.

Ghaderi, M. I., \& Bahrami, Y. (2013). Evaluation of urban design based on urban development principles with emphasis on urban landscape. International Conference on Reconstruction, Architecture and Urban Development Engineering, Tabriz.

Hasheminejad, A. et al. (2012). Development and reconstruction projects with emphasis on compressed city. Fourth Conference on Urban Planning and Management, Mashhad.

Marshall, S., \& Barnette, J. (2011). Urban coding and planning.

Mehrazan Consulting Engineers. (2013). Report of local project of Qarani and Horeameli streets neighborhood with urban design approach. Architecture and Urban Development Department of Mashhad Municipality.

Rahnem, M. R. (2008). A research on urban detailed projects. Jahad Daneshgahi Press, Mashhad.

Rahnem, M. R. (2009). Planning the central regions of the city, 121. Ferdowsi University Press, Mashhad.

Rahnem, M. R., \& Abaszadeh, G. (2008). Measuring the physical form of the city. Jahad Daneshgahi Press, Mashhad.

Rahnem, M. R., Roshani, P., \& Afshari, M. (2012). Qualitative development of modern urban neighborhoods using new urbanism approach. Geographic and Urban Development Journal, 3.

Supreme Council of Urban Development and Architecture. (2008). Housing, architecture and urban development regulations and reconstruction projects. Housing and urban development ministry, Tehran.

Talen, E. (2010). Help for urban planning: The Tracsect strategy.

Talen, E. (2013). Zoning for and against sprawl: The case for form-based codes. Journal of Urban Design, 18. Arizona.

Talen, E., \& Duany, A. (2007). Transect planning.

Zare, M. et al. (2013). Analysis of urbanism principles role in sustainable urban development of Mashhad metropolises. First National Conference on Geography, Urbanism and Sustainable Development, Tehran.

Ziari, K., Ahadnejad, R. M., \& Gherekhloo, M. (2010). Modeling the structural vulnerability of cities against earthquake using AHP in GIS. Geography and Development Journal, 19, 175. Zahedan.

\section{Copyrights}

Copyright for this article is retained by the author(s), with first publication rights granted to the journal.

This is an open-access article distributed under the terms and conditions of the Creative Commons Attribution license (http://creativecommons.org/licenses/by/3.0/). 